\section{FAUNA OF PROTECTED AREAS - 6 WATER BIRDS OF BUXA TIGER RESERVE, WEST BENGAL}

\section{S. Sivakumar and Vibhu Prakash}

Bombay Natural History Society, Hornbill House, S.B. Singh Road, Mumbai, Maharashtra 400023, India.

Buxa Tiger Reserve $\left(26^{\circ} 30^{\prime}-26^{\circ} 55^{\prime} \mathrm{N} \& 89^{\circ} 20^{\prime} \& 8^{\circ} 55^{\prime} \mathrm{E}\right)$ is situated in Jalpaiguri District of West Bengal. The Reserve spreads over an area of $760 \mathrm{sq} \mathrm{km}$ with the core area being 385 sq $\mathrm{km}$. The northern boundary of the Reserve is along the international boundary of Bhutan. The eastern part of the Reserve ends with the boundary of Assam. The western and southern boundaries are bordered by tea gardens, agricultural fields and human settlements. There are 37 villages inside and 33 tea gardens on the fringes of the Reserve. The forest of Buxa is broadly classified as tropical moist-deciduous forest (Champion \& Seth, 1968). The temperature ranges from a maximum of $32^{\circ} \mathrm{C}$ to minimum of $12^{\circ} \mathrm{C}$ and the average annual rainfall is $4100 \mathrm{~mm}$. The altitude of the Reserve varies from ca. $60 \mathrm{~m}-1750 \mathrm{~m}$.

The Reserve is intercepted by several rivers (Rydak, Bala, Jainty, Dima) and perennial streams. A small stagnant waterbody ( $\sim 1.3 \mathrm{~km}$ long \& $\sim 50 \mathrm{~m}$ wide) called Naratali is found in the Reserve. These are the important wetlands of the Reserve that attract a variety of waterbirds. A regular monitoring of waterbirds (presence/absence) was attempted in Rydak (near Bhutanghat guest house) and Dima (in Dima Beat) rivers and, monthly population counts (only for larger birds such as egrets, herons, duck, teals \& storks) were made in Naratali during the winter of 2000-2001. The Reserve is well known for its diversified forest bird species but not known to many as an important water bird area.

Forty-five water bird species were recorded from the Reserve during the study period (Table 1). Beside these, water dependant birds such as Osprey Pandion haliaetus, Brahminy Kite Haliastur indus, Western Marsh-Harrier Circus aeruginosus, Eastern Marsh-Harrier Circus spilonotus, Plumbeous Redstart Rhyacornis fuliginosus, White-capped Redstart Chaimarrornis leucocephalus, Kingfishers (Whitebreasted, Brown-winged, Ruddy, Small Blue \& Lesser Pied), forktails (Little, Black-backed and Slaty-backed) and wagtails (White, Large Pied \& Yellow) were also seen regularly around the waterbodies of the Reserve.

Totally, 13 species of waterbirds were recorded in January and a maximum population of 313 birds were recorded in February at Naratali (Fig. 1). Naratali is an important wetland of the Reserve. A pair of Lessser Adjutant-stork Leptoptilos javanicus (a Red Data Book species) was seen regularly around the wetland. Once a Coot was recorded from the area. The species was not reported earlier from the Reserve (see Allen et al., 1996), which is almost outside of its distributional range

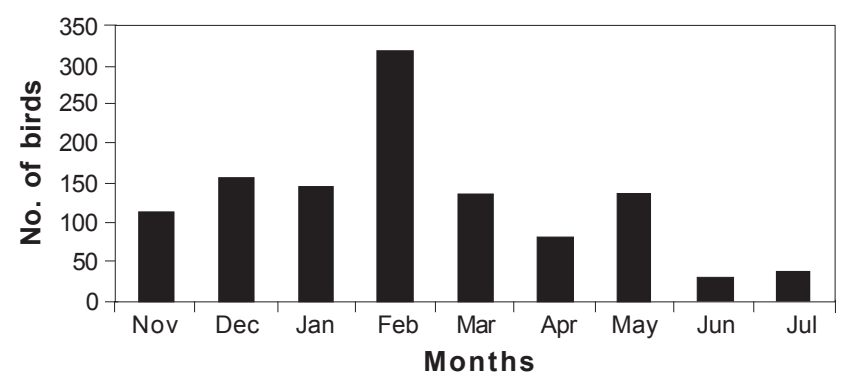

Figure 1. Water bird population in various months in Naratali (in Buxa Tiger Reserve) during 2000-2001

(Grimmett et al., 1998; Kazmierczak, 2000).

Two small breeding colonies (about 30 pairs in each) of Small Pratincole Glareola lactea was seen in Bala Riverbed of Jainty Range. One nest of Malayan Night-Heron Gorsachius melanolophus was seen near Jindabala stream in Checko-23 $3^{\text {rd }}$ Mile Tower road. The Rydak Riverbed is the only place, where Ibisbill Ibidorhyncha struthersii can be sighted in Buxa Tiger Reserve. We saw them in pairs and in small parties of four to six birds along the River near Bhutanghat guesthouse and adjoining areas during our visits in 1999-2001. Stevens (1925) has seen Ibisbill frequently in small parties on the Rydak River in January 1922 in Bhutanghat area. Increasing human population in and around the Reserve, a hydro-electric project of the Bhutan government in the Rydak river system, converting grassland and scrub forest into forest plantation around Naratali may create some adverse effect on the waterbirds of Buxa.

\section{REFERENCES}

Allen, D., J. Anderton and K. Kazmierczak (1996). Report on an Ornithological visit to Buxa Tiger Reserve, West Bengal, India, 17 February to 6 March 1992. Forktail 12: 31-37.

Champion, H.G. and S.K. Seth (1968). A Revised Survey of the Forest Types of India. Manager of Publication, Delhi.

Grimmett, R., C. Inskipp and T. Inskipp (1998). Birds of the Indian Subcontinent. Oxford University Pres, Delhi, 888pp.

Kazmierczak, K. (2000). A Field Guide to the Birds in India, Sri Lanka, Pakistan, Nepal, Bhutan, Bangladesh and the Maldives. OM Book Service, New Delhi, 353pp.

Manakadan, R. and A. Pittie (2001). Standardised common and scientific names of the birds of the Indian Subcontinent. Buceros 6(1): 1-37.

Stevens, II. (1925). Notes on the birds of Sikkim Himalayas. Part 4 (Conclusion). Journal of the Bombay Natural History Society 30: 872-893.

\section{ACKnowledgement}

We express our sincere thanks to Forest Department, West Bengal for financial support, necessary permission and co-operation and Elbert Sangma, driver, Raja Sen and Dillip Roy, field assistants for their help in 
Table 1. Waterbirds recorded in the major wetlands of Buxa Tiger Reserve, West Bengal.

\begin{tabular}{|c|c|c|c|c|}
\hline English name & Scientific name & 1 & 2 & 3 \\
\hline Little Grebe & Tachybaptus ruficollis & + & - & - \\
\hline Little Cormorant & Phalacrocorax niger & - & + & - \\
\hline Great Cormorant & Phalacrocorax carbo & + & + & + \\
\hline Little Egret & Egretta garzetta & + & - & - \\
\hline Purple Heron & Ardea purprea & - & - & + \\
\hline Median Egret & Mesophoyx intermedia & + & - & - \\
\hline Cattle Egret & Bubulcus ibis & + & - & - \\
\hline Indian Pond-heron & Ardeola grayii & + & - & - \\
\hline Little Green Heron & Butorides striatus & + & - & - \\
\hline Black Crowned Night-heron & Nycticorax nycticorax & + & + & - \\
\hline Malayan Night-heron & Gorsachius melanolophus & - & - & + \\
\hline Chestnut Bittern & Ixobrychus cinnamomeus & + & - & - \\
\hline Asian Openbill-Stork & Anastomus oscitans & + & - & - \\
\hline Black Stork & Ciconia nigra & - & + & - \\
\hline Lesser Adjutant Stork & Leptoptilos javanicus & + & - & - \\
\hline Lesser Whistling-Duck & Dendrocygna javanica & + & - & - \\
\hline Brahminy Shelduck & Tadorna ferruginea & - & + & - \\
\hline Cotton Teal & Nettapus coromandelianus & + & - & - \\
\hline Gadwall & Anas strepera & + & - & - \\
\hline Eurasian Wigeon & Anas penelope & + & - & - \\
\hline Mallard & Anas platyrhynchos & + & + & - \\
\hline Spot-billed Duck & Anas poecilorhyncha & + & - & - \\
\hline Northern Pintail & Anas acuta & + & - & - \\
\hline Common Teal & Anas crecca & + & - & - \\
\hline Red-crested Pochard & Rhodonessa rufina & + & - & - \\
\hline Ferruginous Pochard & Aythya nyroca & - & + & + \\
\hline Common Merganser & Mergus merganser & + & - & - \\
\hline White-breasted Waterhen & Amaurornis phoenicurus & + & - & - \\
\hline Common Moorhen & Gallinula chloropus & + & - & - \\
\hline Common Coot & Fulica atra & + & - & - \\
\hline Pheasant-tailed Jacana & Hydrophasianus chirurgus & + & - & - \\
\hline Bronze-winged Jacana & Metopidius indicus & - & - & + \\
\hline Greater Painted-Snipe & Rostratula benghalensis & - & - & + \\
\hline Long-billed Ringed Plover & Charadrius placidus & - & + & - \\
\hline Little Ringed Plover & Charadrius dubius & - & - & + \\
\hline Red-wattled Lapwing & Vanellus indicus & - & - & + \\
\hline River Lapwing & Vanellus duvaucelli & + & + & + \\
\hline Common Greenshank & Tringa nebularia & + & + & + \\
\hline Green Sandpiper & Tringa ochropus & + & + & + \\
\hline Wood Sandpiper & Tringa glareola & - & + & + \\
\hline Common Sandpiper & Actitis hypoleucos & - & + & + \\
\hline LittleStint & Calidris minuta & - & - & + \\
\hline Ibisbill & Ibidorhyncha struthersii & - & - & + \\
\hline Small Pratincole & Glareola lactea & - & - & + \\
\hline \multirow[t]{2}{*}{ Brown Dipper } & Cinclus pallasii & - & + & + \\
\hline & Total & 28 & 14 & 17 \\
\hline
\end{tabular}

+ present; - absent; 1 - Naratali; 2 - Rydak; 3 - Dima

\section{AN OBSERVATION OF A RANID FROG (HOPLOBATRACHUS CRASSUS JERDON, 1853) SWALLOWING A RHACOPHORID (PolYPEDATES MACULATUS GRAY, 1834) IN KALAMETIYA WILDLIFE SANCTUARY, SRI LANKA}

\section{Roshan K. Rodrigo, V.A.M.P.K Samarawickrama, Naalin Perera, M. Sandun, J. Perera, T.N. Peries and C.N.B. Bambaradeniya}

IUCN - The World Conservation Union, 53, Horton Place, Colombo 07, Sri Lanka.

Email: rodrigo_roshan@hotmail.com

with web supplement

The observation of an adult Hoplobatrachus crassus (Jerdon's Bull Frog) swallowing another adult Polypedatus maculatus (Chunam Tree-frog) (Image $1^{\mathrm{w}}$ ) was made at around $2030 \mathrm{hr}$ on 2 November 2002 in Kalametiya Wildlife Sanctuary, Sri Lanka. The location was adjacent to the road leading to Kiula Kalametiya fishing harbor and the habitat was a seasonal pond. The shallow pond had accumulated water from the mid intermonsoon showers. The surrounding vegetation was grasslands and scrublands. Species identification was done by their colour patterns and other morphological characters based on Dutta and Manamendra-Arachchi (1996).

At the edge of the pond the bull frog swallowed P. maculatus slowly by its head. The swallowing took place for about eight minutes after which the bull frog leaped into the water. Bambaradeniya (1997) had recored a H. crassus swallowing a microhylid (Microhyla rubrum) in a rice field at Bathalagoda, Sri Lanka.

Microhyla ornata (Ornate narrow mouth frog), Limnonectes limnocharis (Common Paddy Field Frog) and Uperodon systoma (Baloon Frog) were also recorded from the same pond during the time of observation.

\section{REFERENCE}

Bambaradeniya, C.N.B. (1997). Observation of a Ranid (Hoplobatrachus crassus) swallowing a Microhylid (Microhyla rubrum). Lyriocephalus 3(2): 32.

Dutta, S.K. and K. Manamendra-Arachchi (1996). The Amphibian Fauna of Sri Lanka. The Wildlife Heritage Trust, Sri Lanka.

\section{ACKNOWLEDGEMENT}

We would like to thank Dr. Deepani Jayantha for her kind assistance to prepare this short communication.

" See Image 1 at www.zoosprint.org 